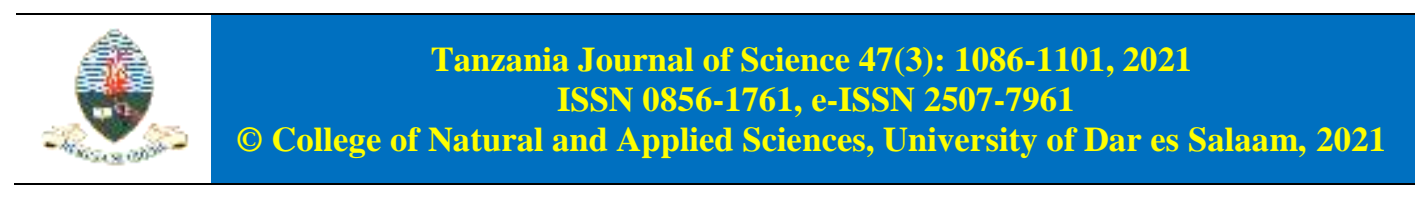

\title{
Mollusc Shells from Neolithic Contexts in the Lake Eyasi Basin, Northern Tanzania
}

\author{
Musa S. Mwitondi*, Albert S. Mjandwa and Pastory M. Bushozi \\ Department of Archaeology and Heritage Studies, University of Dar es Salaam, P. O. Box 35050, \\ Dar es Salaam, Tanzania. \\ *Corresponding author, ORCID: https://orcid.org/0000-0002-2623-7431; e-mail: \\ mussachiko@gmail.com \\ Co-authors, Bushozi ORCID: https://orcid.org/0000-0002-2739-9934; e-mail: \\ pbushozi@gmail.com; Mjandwa e-mail:mjandwa47@gmail.com
}

Received 16 Mar 2021, Revised 9 Jul 2021, Accepted 20 Jul 2021, Published Aug 2021

DOI: https://dx.doi.org/10.4314/tjs.v47i3.19

\begin{abstract}
The study of the Neolithic period in the Lake Eyasi Basin was dominated by attempts to formulate the area's chronology, mobility, settlement patterns, subsistence, and cultural capabilities of Neolithic people as attested by domesticated animals, pottery, and lithic artefacts. Occasionally, studies on molluscs were mentioned, but rarely described in detail. Neolithic sites across the Lake Eyasi Basin have yielded remains of both terrestrial (gastropods) and freshwater mollusc shells (mussels). The abundance of mollusc shell remains in the archaeological records of the Lake Eyasi Basin have played a great role in chronological settings, mobility and community integrations, studies of settlement patterns, and other analyses. Mollusc remains have often been widely interpreted as a food supplement to other reliable food resources such as meat, vegetables and fish. Archaeological excavations and detailed analysis of the shells from Mumba rock shelter, Jangwani 3 and Laghangasimjega 2 have shown that molluscs played different roles. They were effectively used in tool manufacturing, as practical implements for handling objects, as scraping tools, as harpoons for fishing weapons, and sometimes for symbolism and in rituals. Terrestrial and freshwater molluscs coexisted in the Lake Eyasi Basin and were utilised equally by the Neolithic people during the Mid-Holocene period.
\end{abstract}

Keywords: Mollusc shells, Neolithic, Lake Eyasi Basin, Northern Tanzania.

\section{Introduction}

The Neolithic period between 5000-1200 BP marked the beginning of animal domestication in the East African Rift Valley (Bower 1991, Ambrose 1998, Lane 2004, Grillo et al. 2018, 2020, Prendergast et al. 2019, Wang et al. 2020). The period is associated with the use of stone artefacts such as ground and grinding stones, stone axes, stone bowls, and microliths; the use of pottery such as Narosura, Elmenteitan, and Nderit traditions; and domestication of cattle, goat, sheep, and donkey (Bower 1991, KaregaMunene 1996, Gifford-Gonzalez 2000, Rubaka 2002). The Neolithic represents a profound stage in human history when hunting and gathering subsistence modes were in small part replaced by pastoralism and sedentary life (Lane et al. 2007, Wright 2011). During this time, subsistence patterns and tool pool became more diversified as more resources were utilised (Marshall 1990, 2000, Prendergast 2008). On the other hand, molluscs have served 
as critical resources to humans during the Pleistocene-Holocene epochs.

Shell remains are abundant at many Neolithic deposits dating from the MidHolocene, and they have been used to infer past environments and trends for environmental changes over time and space. They also played a key role in creating a better understanding of past human diets, systems of mobility and human interactions between landscapes and seascapes, and processes for making and using tools. Shell remains have also been used as body adornments and for medicinal purposes (Bushozi et al. 2017, Walz 2017, Bushozi 2020). Despite their abundance in archaeological assemblages, shell remains have been given a fringe interpretation compared to other archaeological materials such as pottery, lithic, and fauna remains. At the Lake Eyasi Basin, mollusc remains have been given a cameo role in the work of previous researchers. Even in those fewer instances, mollusc remains were often considered as part of either dietary systems or for their utilitarian functions, or as proxies for chronological settings through radiocarbon dating, electron spin resonance (ESR) dating, and palaeoenvironment reconstructions (Mehlman 1989, Bushozi et al. 2020).

Mehlman (1989) noted that the mollusc shells at Mumba rock shelter were probably utilised as spoons rather than as food. He used ethnographic observations of the site with the Hadza, who use mollusc shells as spoons rather than tools. However, most studies emphasise the use of molluscs as proxies for reconstruction environments and diets (Walz 2017). Several scholars have reported various Achatina and bivalve species (sp.) at Mumba rock shelter (Mehlman 1989, Prendergast et al. 2007, 2014, Bushozi et al. 2017, Bushozi 2020). Mehlman (1989) reported the presence of Burtoa nilotica and bivalves which he categorized the latter as Unio (a genus of freshwater bivalves), which this study categorizes as Corbicula (a genus of freshwater bivalves). This study also specified the Burtoa nilotica giraudi species and identified additional species such as Corbicula sp., Coelatura sp., Limicolaria sp., Burtoa nilotica giraudi, Achatina spp., and Limicolariopsis sp. Collected samples play great importance for the broader understanding of the environmental history, subsistence strategies, and other anthropogenic actions during the Neolithic period in the Lake Eyasi Basin and other places across the globe.

\section{Study Area}

The study was carried out in the Lake Eyasi Basin in Arusha Region, northern Tanzania (Figure 1). Lake Eyasi is a shallow, alkaline lake, sitting at approximately 1000 metres above sea level, and the area lies between latitude $3^{\circ} 20^{\prime} 4.5^{\prime} \mathrm{S}$ and longitude $34^{\circ}$ 50'35.3'E (Rubaka 2002, Prendergast 2008). Lake Eyasi has no outlet, and its chief inlets come from Sibit, Barai, and Wembere Rivers (Bushozi et al. 2017). Current observations show that the lake is filled with sediments and that there is minimal slope bringing other fill (Prendergast et al. 2014, Bushozi et al. 2017, 2020). The lake basin is surrounded by semiperennial springs and river tributaries; some are thermal springs, while others are freshwater (Mehlman 1989, Rubaka 2002, Prendergast 2008). It is possible that natural springs that characterise the Lake Eyasi Basin were the source of fresh water, and they also attracted human and animal habitats around them. Despite being equipped with seasonal water supply through natural river tributes, the local environment of the Lake Eyasi Basin is subjected to semi-arid climatic conditions with colossal storm winds and a small duration of rainfall of about 300-600 mm (Bushozi 2015). Insufficient precipitation is an ideal factor for the fluctuation in lake levels, which is critical in the dry seasons, as sometimes the lake may dry out and leave shallow patches of water reservoirs or ponds. During dry seasons, dry mudflats are routinely exposed across the lakeshore (Domínguez-Rodrigo et al. 2007, Prendergast et al. 2007). 


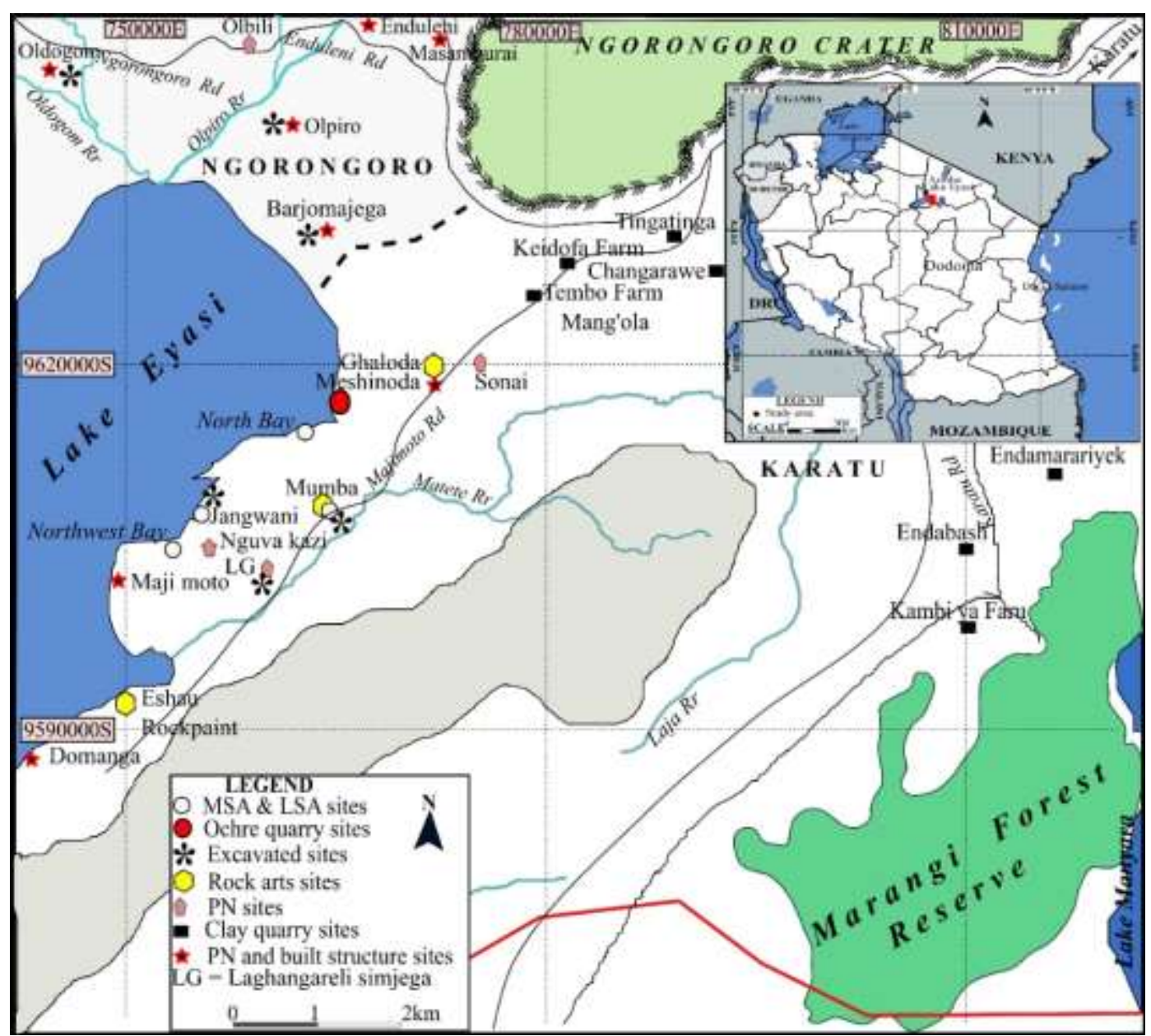

Figure 1: Map of Tanzania showing the locations of Mumba, Jangwani, and Laghangasimjega (Source: Field Data, 2019).

\section{Background Information}

Archaeological expeditions in the Eyasi Basin began in the 1930s with the work of Kohl-Larsen, which documented both rock shelters and open-air sites (Kohl-Larsen 1943, Mehlman 1989). Among the rock shelters, Mumba, Njarasa, Laghangasimjega, and Sonai are notable in the Eyasi landscape, and they have yielded numerous and varied archaeological materials ranging from the Middle Stone Age (MSA), Later Stone Age (LSA), Neolithic, Iron Age (IA), and the historical period (Bushozi 2015, Bader et al. 2020). Mehlman (1989) is known for his role in studying the MSA-LSA transitional industry at Mumba and the refinement of the site's stratigraphy, documenting the burial cairns in the Eyasi Basin, and extensive documentation of the archaeology of northern Tanzania. He also recorded and dated Neolithic and Iron Age cultures in the topmost beds at Mumba.

Other scholars (Mabulla 1996, DomínguezRodrigo et al. 2007, Prendergast et al. 2007, Bushozi et al. 2020, Bushozi 2020) have studied Mumba MSA-LSA cultures in detail and have thereby shown that the shelter was used as a refugia for most of the Upper Pleistocene when the region's climate 
conditions were unstable characterized by short burst rainfall and many prolonged series of dry-arid episodes. The study is confined to Bed II and Upper Bed III in Mumba, which represent Neolithic contexts with diagnostic potsherds attributed to Kansyore, Nderit, Narosura, and Lelesu. These beds also contain fauna remains (mostly wild taxa), LSA artefacts, beads, mollusc shells (sometimes referred to as "shell midden"), and human burials (Mehlman 1989, Prendergast et al. 2007, 2014).

On the other hand, scholars such as Rubaka (2002), Prendergast (2008, Prendergast et al. 2014) have all studied the Neolithic deposits in open-air sites in the Eyasi Basin, particularly at Jangwani 2. Their investigations have uncovered several Neolithic potteries of Narosura tradition, along with a wide range of fauna remains of aquatic, domestic, and wild taxa. They also reported molluscs, ostrich eggshells and lithics, and burial cairns. Previous research overlooked the aspects of molluscs by giving them a fringe archaeological interpretation as remnants of supplementary diet (Rubaka 2002). A similar interpretation was provided by Mehlman (1989) following analysis of the Burtoa nilotica and Unio species in Bed II and Bed III of Mumba. In general, mollusc shells have been broadly interpreted as potential nutritional supplements for necessary subsistence needs (Mehlman 1989, Walz 2017), or their symbolism (Miller et al. 2018, Bushozi 2020). However, there are no further assessments in terms of the recycling and utilization of external shells widely represented in archaeological records. Thus, there is a significant research gap regarding the comprehensive roles of molluscs. Hence, this study analysed both molluscs and ostrich eggshells from Lake Eyasi Neolithic contexts, but our discussion focuses much on terrestrial and freshwater molluscs because they were widely marginalized in the previous studies.

\section{Materials and Methods}

This study conducted three excavations in the Lake Eyasi Basin to uncover subsurface archaeological data to establish the molluscs' role for Neolithic people who inhabited the area. In both prehistoric and modern times, mollusc shells have been equated with utilitarian functions such as the use of shells as spoons. They have also been used as tools and as symbolic revealing artefacts such as beads, pendants, and necklaces (Mehlman 1989, Walz 2017, Bushozi 2020). The study employed a purposive sampling procedure to select the three archaeological excavation units in the Lake Eyasi Basin. The history of site excavations, or the densest scatter of surface archaeological materials, guided and dictated the establishment of archaeological excavation units. Since Mumba rock shelter and Jangwani sites have a long history of archaeological excavations (Kohl-Larsen 1943, Mehlman 1989, Prendergast et al. 2007, 2014, Gliganic et al. 2012, Bushozi et al. 2017, Bushozi 2020), it was reasonable to use a purposive sampling strategy to avoid re-excavating previously excavated units. However, most early researchers were interested in the MSA and LSA sequences and the transitional period between them (Mehlman 1989, Prendergast et al. 2007, Gliganic et al. 2012, Bushozi et al. 2017, Bushozi et al. 2020, Bushozi 2020). To access later culture, we established a new excavation unit (10) at Mumba in less disturbed contexts, and we also used the site's sketch maps established by previous researchers (Mehlman 1989, Prendergast et al. 2007, 2014, Bushozi et al. 2017). Excavation unit 10 lacked the uppermost (Bed I) of Mumba cultural sequences (Mehlman 1989) that barely suffered from erosion agents (running water, storm wind, and animal trampling) together with anthropogenic actions (burial activities and animal grazing).

Jangwani site was previously studied by Rubaka (2002) and Prendergast (2008), and they both reported the lack of stratified archaeological sequences and some archaeological materials in upper levels were 
found in disturbed contexts due to postdeposition processes. A new excavated unit at Jangwani (unit 3) was established in areas with dense surface scatters, but not affected by human activities such as burial practices. Excavation practices also revealed that the excavated trench was not affected by percolation of underground water and bioturbation of roots or burrowing animals. Bioturbation or percolation of water reservoirs are the primary causes of chemical alteration of archaeological artefacts through carbonation processes (Douka et al. 2010, Philippsen 2013). At Laghangasimjega unit 2, a purposeful selection of the area to excavate was driven and dictated by the densest surface exposure of archaeological materials almost 60 metres from the current Barai River. The selection of an area to establish an excavation unit was carefully done by considering the area's previous research history, which prevented stumbling upon the previous excavations (Kohl-Larsen 1943, Mehlman 1989).

Based on sampling strategies outlined earlier, especially on the three excavation units that were established at Mumba rock shelter, Laghangasimjega, and Jangwani, sites were assigned identification numbers to differentiate them from previous excavation units. The setting of the excavation units followed a grid system in which each grid (sub-unit) was divided into quarters of a metre (25 centimeters). An automated Total Station (Leica TS 16) device was used to map out in three dimensions (3D) the spatial distribution of archaeological materials during excavation processes. Both arbitrary layers of five centimetres $(5 \mathrm{~cm})$ apart and natural strata were followed during the excavation processes, and soils were dry sieved through a three millimetre $(\mathrm{mm})$ wire mesh to recover smaller objects such as beads. Excavation tools such as trowels, dustpans, shovels, brushes, and buckets, together with necessary accessories like recording forms and a Munsell Soil Colour Chart, were employed.

The recovered materials were mapped, recorded, and bagged separately, and datable materials such as charcoal, shells, and beads were identified and collected accordingly. Wall profiles illustrating the stratigraphy of an excavation unit were drawn, whereas backfilling of excavated units was observed after Joukowsky (1980). The sample size for this study was archaeological materials retrieved from subsurface archaeological contexts. The archaeological materials include pottery, lithic, beads, bones, mollusc shells, ostrich eggshells, and ochre from different stratigraphic sequences at Mumba rock shelter, Jangwani 3, and Laghangasimjega 2. This study only presents molluscs remains collected from Mumba, Jangwani 3, and Laghangasimjega 2; other collected samples will be presented elsewhere. The mollusc shells were analysed following Debruyne's (2010) scheme.

This study used both the Number of Identifiable Species (NISP) and Minimum Number of Individuals (MNI) techniques as counting measures and weight methods for studying the mollusc shells from the lake's Neolithic context, the Eyasi Basin. However, each method has its strengths and weaknesses. For example, NISP tends to give the general occurrence of a species in the assemblage, but often leads to individual overestimation. The reliability of the MNI and the weight depend on the research questions being addressed. Weight could have been a useful measure for comparing the number of shells (undifferentiated by species) to other site components, but it is far less reliable for comparing taxonomic abundances because shell weights vary by taxa (heavy clam shells vs. lighter mussel shells) (Mason et al. 1998). Thus, this study chose to use counting and weighing methods to check and establish the roles of molluscs in the Eyasi basin during Neolithic times.

\section{Results}

A total of 23,646 shell remains were analysed by NISP and MNI counting measures in which 23,366 were gastropods (99.81\%), 231 mussels $(0.97 \%)$, and 49 ostrich shells 
$(0.02 \%)$. The majority of samples analysed were from Mumba, where gastropods totalled 22,869 specimens, mussels 199 specimens and ostrich shells 49 specimens. In addition, there was only one tortoise shell and 36 pieces were unidentified (Table 1). The following species were identified at Mumba: Corbicula sp. Coelatura sp., Achatina fulica, Limicolaria sp, Burtoa nilotica giraudi, Limicolariopsis sp. and Achatinia spp. Some of the shells analysed were considered indeterminate because of fragmentation or carbonate concretions that obscured the methods of analysis (Plate 1). The NISP include Corbicula sp. (181), Coelatura sp. (17), Achatina fulica (420), Achatina spp. (83), Limicolaria sp. (26), Burtoa nilotica giraudi (43), and Limicolariopsis sp. (10). In all, 22,259 were highly fragmented and were designated as indeterminate.

The MNI shows that three species were present in Mumba. These include Corbicula sp., (4), Coelatura sp. (1), and Achatina fulica (37) species. The mollusc assemblage also consists of Limicolaria sp. (15), Burtoa nilotica giraudi (20), Limicolariopsis sp. (4), and Achatina spp. (3). Analysis of surface modifications indicates that 14 shells were burned at one point, while eight shells also showed signs of perforation. Habitat analysis indicates that the majority of mollusc remains were terrestrial species (22327), while 196 were fresh water and 517 were indeterminate (Figure 2). The total weight of all shells was 9603 grams, indicating that a modest amount of molluscs were utilised at Mumba.

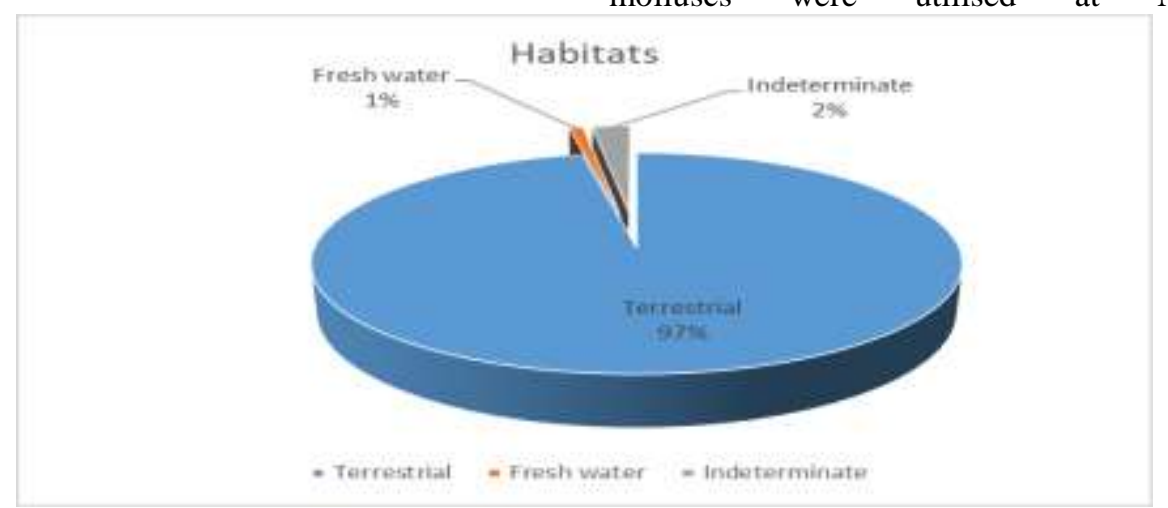

Figure 2: Percentage distribution of mollusc habitats (Source: Field Data, 2019).

Table 1: Frequency distribution of shell types at Mumba rock shelter

\begin{tabular}{|l|c|c|c|c|c|}
\hline Level & Mussels & Gastropods & Ostrich & Turtle & Indeterminate \\
\hline $\mathbf{1}$ & 0 & 514 & 6 & 0 & 0 \\
\hline $\mathbf{2}$ & 10 & 597 & 6 & 1 & 2 \\
\hline $\mathbf{3}$ & 1 & 163 & 2 & 0 & 15 \\
\hline $\mathbf{4}$ & 54 & 1140 & 5 & 0 & 19 \\
\hline $\mathbf{5}$ & 13 & 1786 & 3 & 0 & 0 \\
\hline $\mathbf{6}$ & 84 & 9510 & 15 & 0 & 0 \\
\hline $\mathbf{7}$ & 33 & 7862 & 12 & 0 & 0 \\
\hline $\mathbf{8}$ & 4 & 1297 & 0 & 0 & 36 \\
\hline Total & 199 & 22869 & 49 & 1 & 0 \\
\hline Sour & & & & & 0 \\
\hline
\end{tabular}

Source: Field Data, 2019. 

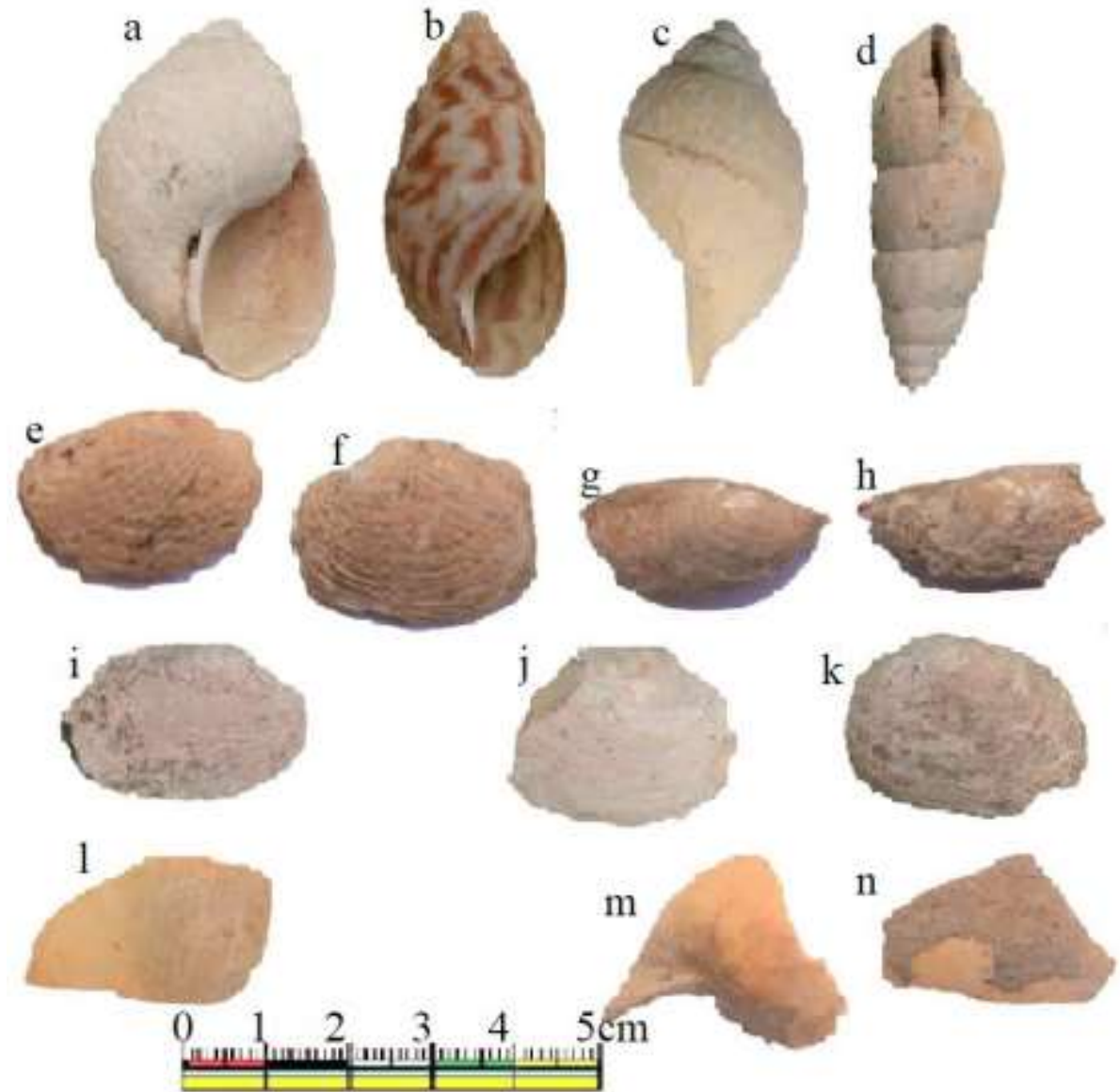

Plate 1: $\mathrm{a}=$ Achatina fulica, $\mathrm{b}=$ Limicolaria $s p ., \mathrm{c}=$ Burtoa nilotica giraudi, $\mathrm{d}=$ Limicolariopsis sp., e-h = Coelatura $\mathrm{sp} ., \mathrm{i}-\mathrm{k}=$ Corbicula $\mathrm{sp} ., \mathrm{l}-\mathrm{n}=$ Achatina $\mathrm{spp}$. Source: Field Data, 2019.

There was a noticeable increase in the number of molluscs at levels below 4 to 8 (Table 1), but the species Achatina fulica, Corbicula and Achatinia spp., were consistent throughout the stratigraphy. In addition, Limicolariopsis sp., and Coelatura sp., species were distributed unevenly across the stratigraphy (Tables 2 and 3). The analysis of mollusc shell surface modifications indicated that 14 shells were exposed to fire at some points in which the upper levels (1 and 2) contains the highest number of burnt shells compared to the lower levels. Similarly, the mollusc assemblage in Mumba exhibits a moderate number of intentional perforation practices (Table 4, Plate 2). The relative weight of specimens analysed suggests that molluscs were heavily utilised at level 6 of the Mumba sequences (Table 5). As mentioned above, terrestrial molluscs dominate the freshwater taxon. 
Table 2: Frequency distribution of mollusc taxon NSIP per level at Mumba

\begin{tabular}{|c|c|c|c|c|c|c|c|c|}
\hline Level & 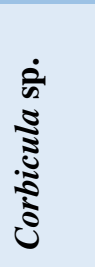 & 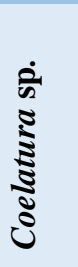 & 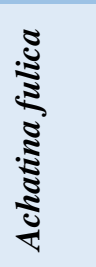 & 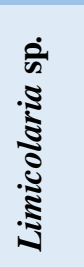 & 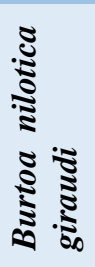 & 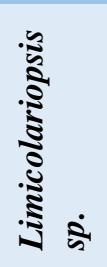 & 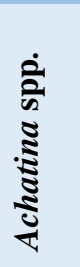 & 葛 \\
\hline 1 & 0 & 0 & 0 & 9 & 1 & 1 & 46 & 456 \\
\hline 2 & 10 & 0 & 13 & 0 & 0 & 0 & 7 & 577 \\
\hline 3 & 0 & 0 & 15 & 3 & 0 & 0 & 9 & 139 \\
\hline 4 & 50 & 4 & 61 & 3 & 2 & 0 & 8 & 1085 \\
\hline 5 & 12 & 1 & 35 & 0 & 3 & 0 & 1 & 1737 \\
\hline 6 & 82 & 2 & 234 & 10 & 25 & 3 & 5 & 9231 \\
\hline 7 & 23 & 10 & 48 & 1 & 9 & 2 & 5 & 7764 \\
\hline 8 & 4 & 0 & 14 & 0 & 3 & 4 & 2 & 1270 \\
\hline Total & 181 & 17 & 420 & 26 & 43 & 10 & 83 & 22259 \\
\hline
\end{tabular}

Source: Field Data, 2019.

Table 3: Frequency distribution of shell surface modification per level at Mumba rock shelter

\begin{tabular}{|l|c|c|c|c|c|}
\hline Level & Burnt & Perforated & Shaped & Polished & Indeterminate \\
\hline $\mathbf{1}$ & 4 & 0 & 0 & 0 & 510 \\
\hline $\mathbf{2}$ & 4 & 1 & 0 & 0 & 594 \\
\hline $\mathbf{3}$ & 0 & 0 & 0 & 0 & 175 \\
\hline $\mathbf{4}$ & 3 & 0 & 0 & 0 & 1213 \\
\hline $\mathbf{5}$ & 1 & 1 & 0 & 0 & 1784 \\
\hline $\mathbf{6}$ & 0 & 3 & 0 & 0 & 9591 \\
\hline $\mathbf{7}$ & 2 & 3 & 0 & 0 & 7857 \\
\hline $\mathbf{8}$ & 0 & 0 & 0 & 0 & 1297 \\
\hline Total & $\mathbf{1 4}$ & $\mathbf{8}$ & $\mathbf{0}$ & $\mathbf{0}$ & $\mathbf{2 3 0 2 1}$ \\
\hline
\end{tabular}

Source: Field Data, 2019. 


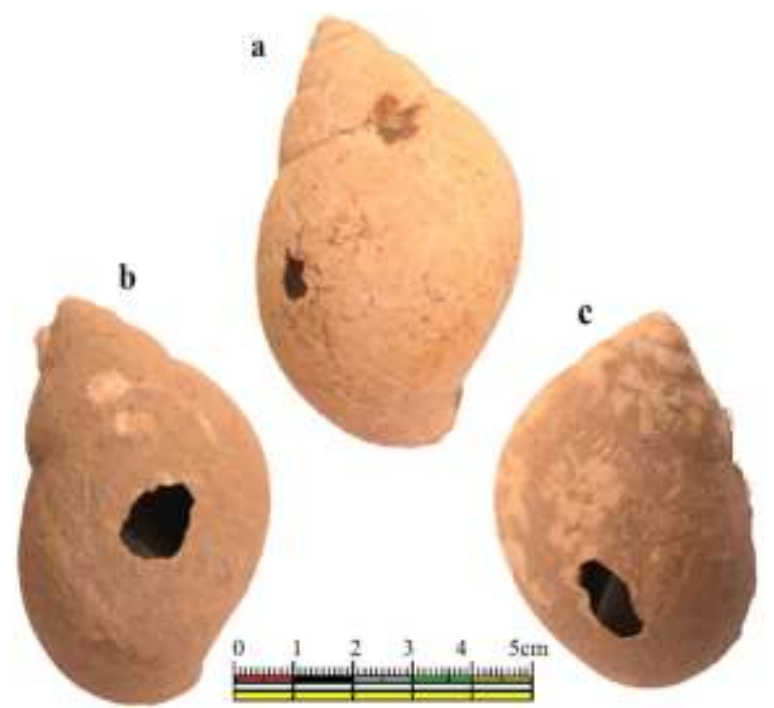

Plate 2: a, b, c-Perforated Achatina fulica with coated carbonate on the surface Source: Field Data, 2019.

Table 4: Frequency distribution of mollusc habitats per level at Mumba

\begin{tabular}{|l|c|c|c|}
\hline Level & Terrestrial & Freshwater & Indeterminate \\
\hline $\mathbf{1}$ & 7 & 0 & 502 \\
\hline $\mathbf{2}$ & 591 & 10 & 2 \\
\hline $\mathbf{3}$ & 163 & 0 & 13 \\
\hline $\mathbf{4}$ & 1159 & 54 & 0 \\
\hline $\mathbf{5}$ & 1775 & 11 & 0 \\
\hline $\mathbf{6}$ & 9510 & 84 & 0 \\
\hline $\mathbf{7}$ & 7829 & 33 & 0 \\
\hline $\mathbf{8}$ & 1293 & 4 & 0 \\
\hline Total & $\mathbf{2 2 3 2 7}$ & $\mathbf{1 9 6}$ & $\mathbf{5 1 7}$ \\
\hline
\end{tabular}

Source: Field Data, 2019. 
Table 5: Distribution of mollusc species on weight per level at Mumba rock shelter

\begin{tabular}{|c|c|c|c|c|c|c|c|c|c|}
\hline $\begin{array}{l}\bar{d} \\
\stackrel{d}{\lrcorner}\end{array}$ & 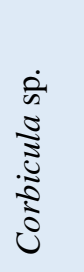 & $\begin{array}{l}\dot{0} \\
\tilde{0} \\
\stackrel{0}{\Xi} \\
\frac{\tilde{\Xi}}{\tilde{U}} \\
\tilde{\Xi}\end{array}$ & 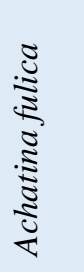 & 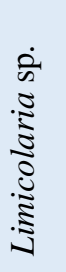 & 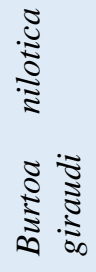 & 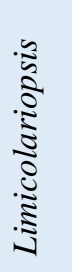 & 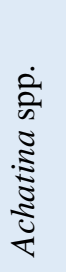 & 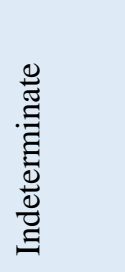 & $\begin{array}{l}E \\
0,0 \\
\vec{E} \\
\frac{0}{00} \\
\overrightarrow{3} \\
3\end{array}$ \\
\hline 1 & 0 & 0 & 0 & 9 & 1 & 1 & 46 & 456 & 149.8 \\
\hline 2 & 10 & 0 & 13 & 0 & 0 & 0 & 7 & 577 & 130.4 \\
\hline 3 & 0 & 0 & 15 & 3 & 0 & 0 & 9 & 139 & 55.3 \\
\hline 4 & 50 & 4 & 61 & 3 & 2 & 0 & 8 & 1085 & 886.9 \\
\hline 5 & 12 & 1 & 35 & 0 & 3 & 0 & 1 & 1737 & 737.6 \\
\hline 6 & 82 & 2 & 234 & 10 & 25 & 3 & 5 & 9231 & 4020.8 \\
\hline 7 & 23 & 10 & 48 & 1 & 9 & 2 & 5 & 7764 & 3012 \\
\hline 8 & 4 & 0 & 14 & 0 & 3 & 4 & 2 & 1270 & 610.2 \\
\hline Total & 181 & 17 & 420 & 26 & 43 & 10 & 83 & 22259 & 9603 \\
\hline
\end{tabular}

Source: Field Data, 2019.

\section{Distribution of Molluscs at Jangwani 3}

The shells from the Jangwani 3 assemblage are represented by mussels (3), gastropods (303), ostriches (30) and undetermined individuals (918). The NISP analyses included Corbicula sp., (3), Achatina fulica (335), and indeterminate (918) (Table 6). The MNI analysis included Achatina fulica (31). On the other hand, the analysis of surface modifications revealed that 56 shells had black spots (colour) suggesting that they had been exposed to fire at some point. Four other shells clearly exhibited perforation intentions and 1144 were indeterminate (plate 2). The increased number of indeterminate shells results from fragmentation of the shell and carbonate concretion. For habitation, the analysis revealed that 304 species were terrestrial, while 3 were freshwater and 921 were indeterminate. There are four tool-shaped molluscs in the assemblage (plate 3 ). The weight distribution per level indicates that most mollusc remains occur at lower levels (6-15) with a total of 540 grams indicating that molluscs played a great role in human subsistence and other services. 
Table 6: Frequency distribution of taxon NISP per level at Jangwani 3

\begin{tabular}{|l|c|c|c|}
\hline Level & Corbicula sp. & Achatina fulica & Indeterminate \\
\hline $\mathbf{1}$ & 0 & 11 & 54 \\
\hline $\mathbf{2}$ & 1 & 9 & 13 \\
\hline $\mathbf{3}$ & 0 & 7 & 33 \\
\hline $\mathbf{4}$ & 0 & 7 & 54 \\
\hline $\mathbf{5}$ & 0 & 7 & 77 \\
\hline $\mathbf{6}$ & 0 & 13 & 134 \\
\hline $\mathbf{7}$ & 0 & 14 & 48 \\
\hline $\mathbf{8}$ & 0 & 9 & 32 \\
\hline $\mathbf{9}$ & 0 & 19 & 48 \\
\hline $\mathbf{1 0}$ & 1 & 36 & 87 \\
\hline $\mathbf{1 1}$ & 0 & 72 & 72 \\
\hline $\mathbf{1 2}$ & 0 & 26 & 49 \\
\hline $\mathbf{1 3}$ & 1 & 38 & 59 \\
\hline $\mathbf{1 4}$ & 0 & 26 & 62 \\
\hline $\mathbf{1 5}$ & 0 & 25 & 57 \\
\hline $\mathbf{1 6}$ & 0 & 16 & 39 \\
\hline Total & $\mathbf{3}$ & $\mathbf{3 3 5}$ & $\mathbf{9 1 8}$ \\
\hline Source & 0 & & \\
\hline
\end{tabular}

Source: Field Data, 2019.

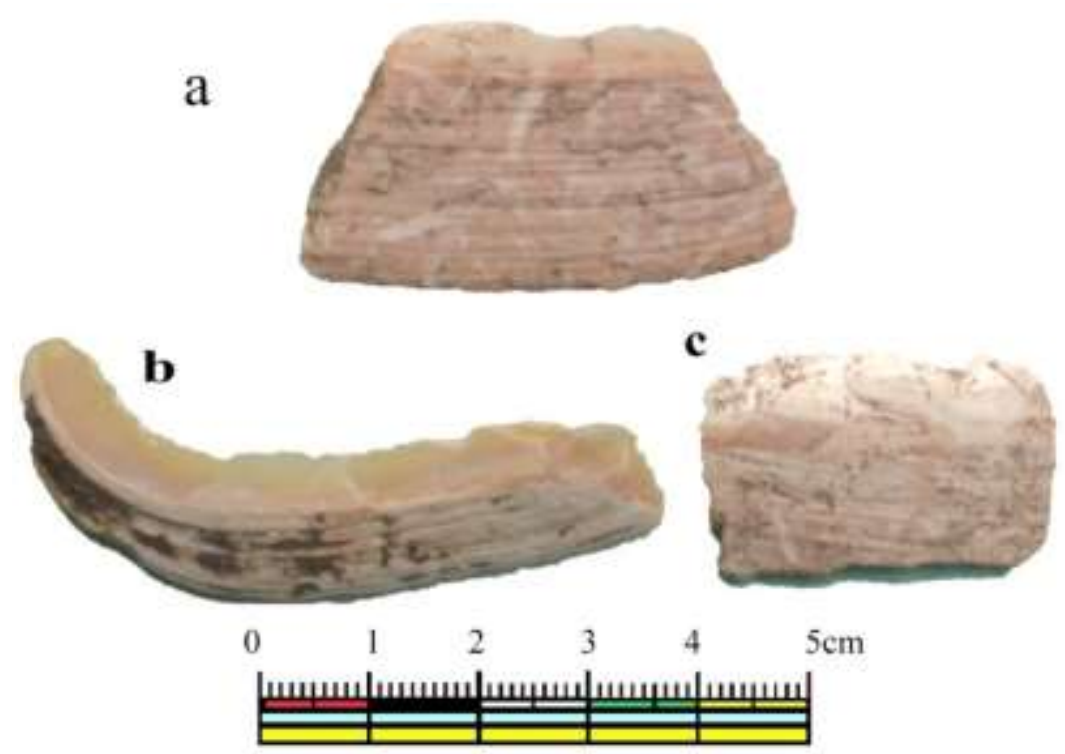

Plate 3: Shaped Corbicula sp. shell at Jangwani 3. Source: Field Data, 2019.

Distribution of molluscs at Laghangasimjega

2

The study examined 29 mussels, 194 gastropods, 51 ostrich shells and 2073 indeterminate shells (Table 7). The mollusc assemblage at Laghangasimjega is represented by Corbicula sp., and Achatina fulica, an indeterminate species. The NISP includes Corbicula sp. (29), Achatina fulica (466), and indeterminate (2073). The MNI contains 
specimens from Achatina fulica (98). The results of the surface modification suggest that 66 shells were burned, one shaped as a tool, the other polished and 2547 indeterminate (Table 8). Habitat analysis indicated that 466 shells were land-based, while 29 shells were fresh water and 2073 shells were indeterminate. All shells had a total weight of $1,776.3$ grams (Table 9).

Table 7: Frequency distribution of shell types per level at Laghangasimjega 2

\begin{tabular}{|l|r|r|r|r|r|}
\hline Level & Mussels & & Gastropods & Ostrich & Indeterminate \\
\hline $\mathbf{1}$ & 4 & 117 & 26 & 776 \\
\hline $\mathbf{2}$ & 24 & 1 & 19 & 856 \\
\hline $\mathbf{3}$ & 1 & 71 & 5 & 310 \\
\hline $\mathbf{4}$ & 0 & 5 & 1 & 107 \\
\hline $\mathbf{5}$ & 0 & 0 & 0 & 19 \\
\hline $\mathbf{1 0}$ & 0 & 0 & 0 & 5 \\
\hline Total & $\mathbf{2 9}$ & $\mathbf{1 9 4}$ & $\mathbf{5 1}$ & $\mathbf{2 0 7 3}$ \\
\hline
\end{tabular}

Source: Field Data, 2019.

Table 8: Frequency distribution of shell surface modification at Laghangasimjega 2

\begin{tabular}{|c|c|c|c|c|}
\hline Level & Burnt & Shaped & Polished & Indeterminate \\
\hline 1 & 12 & 0 & 0 & 885 \\
\hline 2 & 26 & 0 & 1 & 1146 \\
\hline 3 & 27 & 1 & 0 & 381 \\
\hline 4 & 1 & 0 & 0 & 111 \\
\hline 5 & 0 & 0 & 0 & 19 \\
\hline 10 & 0 & 0 & 0 & 5 \\
\hline Total & 66 & 1 & 1 & 2547 \\
\hline
\end{tabular}

Source: Field Data, 2019.

Table 9: Distribution of mollusc species and weight per level at Laghangasimjega 2

\begin{tabular}{|l|r|r|r|r|r|r|}
\hline Level & Corbicula sp. & Coelatura sp. & Achatina fulica & Indeterminate & Weight \\
\hline $\mathbf{1}$ & 4 & 0 & 117 & 776 & 698 \\
\hline $\mathbf{2}$ & 24 & 0 & 273 & 856 & 899 \\
\hline $\mathbf{3}$ & 1 & 0 & 71 & 310 & 141 \\
\hline $\mathbf{4}$ & 0 & 0 & 5 & 107 & 36 \\
\hline $\mathbf{5}$ & 0 & 0 & 0 & 19 & 1.9 \\
\hline $\mathbf{1 0}$ & 0 & 0 & 0 & 5 & 0.4 \\
\hline Total & $\mathbf{2 9}$ & $\mathbf{0}$ & $\mathbf{4 6 6}$ & $\mathbf{2 0 7 3}$ & $\mathbf{1 7 7 6 . 3}$ \\
\hline
\end{tabular}

Source: Field Data, 2019. 


\section{Discussion}

The mollusc remains found in archaeological contexts have generally been studied from the viewpoint of accumulations produced by early human populations when gathering these invertebrate animal species to supplement their nutritional needs. Such uses as one of the significant sources of potential foods to their diet could probably be thought of as the first step whereby Neolithic people consumed diverse resources across their natural landscape. For this reason, molluscs could have played a critical role in their daily food requirements. Elsewhere around the world, at archaeological sites in places such as Jamaica, the Bahamas, and Haiti, molluscs were gathered to be used as the raw material for tool making (Solana et al. 2011).

The remains of mollusc assemblages from the three excavated sites suggest that they were often exposed to the firing process to prepare them as food supplement materials or as an initiative towards tool manufacturing. The marks left by dark spots indicate cooking, while the perforation holes could suggest an intentional human attempt to extract the flesh from the shell. Flesh extraction is a common practice among the major species of Achatina fulica and Burtoa nilotica giraudi are considered as food preferences by past and contemporary societies. Molluscs have been used by humans in a variety of ways: as tools for ritual purposes, decoration, subsistence food, symbolism and tools (Walz 2017, Miller et al. 2018 and Bushozi 2020).

The presence of modified shells on the surface may represent one or more of the reasons mentioned above. The higher number of indeterminate shells is a product of postdeposition history in which most shells at three studied sites (Mumba, Jangwani 3, and Laghangasimjega 2) are fragmented and carbonate. However, deliberate rupture of mollusc shell remains often results from human activities such as dietary needs, symbolism, and the tools manufacture. The mollusc assemblages in the Lake Eyasi Basin contain many terrestrial species, as reflected in the higher frequency of terrestrial species such as Achatina fulica (giant African land snails), which suggests the favourable climatic conditions (in terms of temperature and humidity) in the Lake Eyasi basin in the MidHolocene when northern Tanzania was first inhabited by herding communities. The presence of freshwater mussels such as Limicolariopsis sp., and Coelatura sp., in Upper Bed III at Mumba and Jangwani suggest the existence of river channels or ponds in the surrounding environments. The presence of water bodies is an indicator for the wide assemblage of varied mollusc species in the Neolithic assemblage across the lake basin. Thus, Neolithic habitants exploited freshwater and terrestrial molluscs, and therefore the shells that are abundant in the archaeological records were brought for functional purposes: either as tools, as supplements to diets, or for their symbolism in rituals or personal awareness.

The mollusc assemblage at Jangwani 3 is dominated by Corbicula sp. and Achatina fulica, but the majority of them were highly fragmented due to animal trampling or whirlwind deflation (Rubaka 2002). The closely related practice was revealed at Mumba, where carbonated and fragmented shells appear in higher frequencies. Fragmentation resulted from taphonomic processes, although it can sometimes be related to anthropogenic actions such as their use for scraping or refining ceramics (Debruyne 2010, Solana et al. 2011). The modification of shells for scraping purposes involved transforming natural edges into cutting or scraping edges by retouching their marginal edges (Solana et al. 2011). Some scholars refer to such practice a "nucleiform," indicating the use of large gastropod shells as raw materials for shaping flakes (Solana et al. 2011). However, high frequencies of perforation practices indicate that the snail's soft tissues were carefully removed to serve dietary requirements. The total weight of $11.379 \mathrm{~kg}$ of molluscs collected at Mumba, Jangwani, and Laghangasimjega showed that they deliberately served significant 
roles either as food (as evident from the perforations) or as tools (as shaped shells indicate).

Evidence from Latin America shows that mollusc shells served as knives or as the raw materials to make handled knives of various kinds. In Chile, Melanesia and Argentina, they were used as hooks to catch fish or to produce a cutting machine (Solana et al. 2011). Sometimes they were used as polishers or straighteners to polish different materials (Debruyne, 2010). For example, Guayaquis (Ache) people used freshwater mussel shells for polishing axe handles (Solana et al. 2011). The shells' surface modification revealed in the Lake Eyasi Basin, particularly burnt and shaped or polished edges, suggest that they were commonly used as tools to serve varied activities (Debruyne 2010). The presence of mollusc remains in the Neolithic context at the Lake Eyasi Basin indicated that early herding communities relied on varied foodstuffs, including domesticated and wild animals, plant food, molluscs, and aquatic resources. Although Neolithic culture was dominated by stone artefacts, pottery, and other bone remains, the use of molluscs was inseparable from daily life. This assumption emanates from the moderate weight and increased frequency of molluscs in the Neolithic assemblage. This pattern indicates that Neolithic people in the Lake Eyasi Basin were engaged in varied activities that often involved the gathering of terrestrial and freshwater molluscs as a source of nutrients, but the external shells were recycled to perform other activities.

\section{Conclusions}

Neolithic people in the Lake Eyasi Basin were utilising various pools of resources, which included molluscs. Previous research on the area had suggested that the prehistoric population consumed molluscs as a part of their diets, but this study has expanded the understanding by showing that the molluscs' remains in the Neolithic contexts served multiple functions, such as complementing diets, being a device in tool manufacturing processes, acting as a part of the handle where knives were held, or being used as tools to perform varied activities such as scraping, polishing, or stirring and serving food. They were also used for symbolism, in rituals and ceremonies, and sometimes ironically used as ornaments (beads or necklaces) to express displeasure.

The appearance of terrestrial and freshwater molluscs in the Neolithic contexts at the Lake Eyasi Basin suggested that the East African Rift region featured numerous perennial river tributes and ponds, which are mutual habitation locales for mussels. The dense representation of the giant snails of Africa (Achatina) pleads for the existence of wetlands and shrubs, the distinct natural environment of terrestrial mollusc habitats. The humid environment that characterized the region in the Mid-Holocene was an ideal factor for molluscs' colonisation of the landscape, and in turn, herding communities used the soft un-segmented body of molluscs to attain nourishment essential for the maintenance of their health. External shells were often recycled or altered into ornaments, tools or handling devices. However, more studies are encouraged to attain additional knowledge on the paleoenvironment of the Lake Eyasi Basin and the ways it changed over time, including insights on the human adaptation strategies to an ever-changing environment.

\section{Acknowledgements}

The Volkswagen Stiftung funded this study under Dr Pastory Magayane Bushozi's postdoctoral project 'Evolving human minds, behaviour and subsistence during the Middle to Upper Pleistocene in Tanzania (EHM)', 20132022.

\section{References}

Ambrose SH 1998 Chronology of the Later Stone Age and food production in East Africa. J. Archaeol. Sci. 25: 377-392.

Bader G, Bushozi PM, Will M, Schimid V, Val A, Blessing M, Schmidt P, Conard NJ 2020 Invesitigating the 1930s Kohl-Larsen 
collection from the Lake Eyasi Basin, Tanzania. Mitt. Ges. Urgesch. 29: 93-103.

Bower J 1991 The pastoral Neolithic of East Africa. J. World Prehistory 5(1): 49-82.

Bushozi PGM 2015 An assessment of strategies for cultural heritage management and tourism development in the Eyasi basin, Northern Tanzania. J. Environ. Sci. Eng. B. 4: 661-676.

Bushozi PGM, Luque L, Mabulla AZP 2017 Geochronology and technological development: the microscopic and metric evidence from Middle Stone Age (MSA) points at Mumba rock shelter, Northern Tanzania. Palaeoecol. Afr. 34: 183-206.

Bushozi PGM, Skinner A and Luque L 2020 The Middle Stone Age (MSA) technological patterns, innovations, and behavioral changes at bed via of Mumba rock shelter, northern Tanzania. Afr. Archaeol. Rev. 37: 293-310.

Bushozi PGM 2020 Middle and Later Stone Age symbolism stone beads from Mumba rock shelter in northern Tanzania. Utafiti 15(1): 1-27.

Debruyne S 2010 Tools and souvenirs: the shells from Kilise Tepe (1994-1998). Anatolian Stud. 60: 149-160.

Domínguez-Rodrigo M, Díez-Martín F, Mabulla A Z P, Luque L, Alcalá L, Tarriño A, López-Sáez JA, Barba R and Bushozi P 2007 The archaeology of the Middle Pleistocene deposits of Lake Eyasi, Tanzania. J. Afr. Archaeol. 5(1): 47-87.

Douka K, Higham TFG, and Hedges REM 2010 Radiocarbon dating of shell carbonates: old problems and new solutions. Munibe 31: 19-27.

Gifford-Gonzalez D 2000 Animal disease challenges to the emergence of pastoralism in sub-Saharan Africa. Afr. Archaeol. Rev. 17: 95-139.

Gliganic LA, Jacobs Z, Roberts RG, Domínguez- Rodrigo $\mathrm{M}$ and Mabulla AZP 2012 New ages for Middle and Later Stone Age deposits at Mumba rock shelter, Tanzania: optically stimulated luminescence dating of quartz and feldspar grains. J. Human Evolut. 62 (4): 533-547.

Grillo K, Prendergast M, Contreras D, Fitton T, Gidna A, Goldstein S, Knisley M, Langley M and Mabulla A 2018 Pastoral Neolithic settlement at Luxmanda, Tanzania. J. Field Archaeol. 43(2): 102-120.

Grillo KM, Dunne J, Marshall F, Prendergast M, Casanova E, Gidna A, Janzen A, Karega-Munene, Keute J, Mabulla AZP, Robertshaw P, Gillard T, Walton-Doyle C, Whelton C, Ryan K and Evershed R 2020 Molecular and isotopic evidence for milk, meat, and plants in prehistoric eastern African herder food systems. Proc. Natl. Acad. Sci. U. S. A. 117: 9793-9799.

Joukowsky M 1980 A complete manual of field archaeology: tools and techniques of fieldwork for archaeologists. Prentice-Hall, Englewood Cliffs.

Karega-Munene 1996 The East African Neolithic: an alternative view. Afr. Archaeol. Rev. 13(4): 247-254.

Kohl-Larsen L 1943 Auf den spuren des vormenschen. Strecker und Schröder Verlag, Stuttgart.

Lane P 2004 The 'moving frontier' and the transition to food production in Kenya. Azania XXXIX: 244-64.

Lane P, Ashley C, Seitsonen O, Harvey P, Mire $\mathrm{S}$ and Odede F 2007 The transition to farming in Eastern Africa: new faunal and dating evidence fromWadh Lang'o and Usenge, Kenya. Antiquity 81: 62-81.

Mabulla AZP 1996 Middle and Later Stone Age land use and lithic technology in the Eyasi basin, Tanzania. $\mathrm{PhD}$ thesis, University of Florida.

Marshall F 1990 Origins of specialised pastoral production in East Africa. Am. Anthropol. 92(4): 873-894.

Marshall F 2000 The origins and development of African livestock: archaeology, genetics, linguistics and ethnography. University College London Press, London.

Mason RD, Peterson ML, Tiffany JA 1998 Weighing vs. counting: measurement reliability and the California school of 
midden analysis. Am. Antiq. 63(2): 303 324.

Mehlman MJ 1989 Later quaternary archaeology sequences in northern Tanzania. PhD thesis, Illinois.

Miller JM, Sawchuk EA, Reedman ALR, Willoughby PR 2018 Land snail shell beads in the Sub-Saharan archaeological record: when, where, and why? Afr. Archaeol Rev. 35: 347-378.

Philippsen B 2013 The freshwater reservoir effect in radiocarbon dating. Heritage Sci. 1( 1): 24 .

Prendergast M, Luque, L, Domínguez-Rodrigo M, Diez-Martín F, Mabulla A and Barba R 2007 New excavations at Mumba rockshelter, Tanzania. J. Afr. Archaeol. 5(2): 217-243.

Prendergast M 2008 Forager variability and transitions to food production in secondary settings: Kansyore and pastoral Neolithic economies in East Africa. $\mathrm{PhD}$ thesis, Harvard University, Department of Anthropology.

Prendergast M, Grillo K, Mabulla AZP and Wang H 2014 New dates for Kansyore and pastoral Neolithic ceramics in the Eyasi basin, Tanzania. J. Afr. Archaeol. 12(1): 8998.

Prendergast ME, Lipson M, Sawchuk EA, Olalde I, Ogola CA, Rohland N, Sirak KA, Adamski N, Bernardos R, Broomandkhoshbacht N, Callan K, Culleton BJ, Eccles L, Harper TK, Lawson AM, Mah M, Oppenheimer J, Stewardson $\mathrm{K}$, Zalzala F, Ambrose SH, Ayodo G, Gates HL, Gidna AO, Katongo M, Kwekason A,
Mabulla AZP, Mudenda GS, Ndiema EK, Nelson C, Robertshaw P, Kennett DJ, Manthi FK and Reich D 2019 Ancient DNA reveals a multistep spread of the first herders into sub-Saharan Africa. Sci. 365: 6448.

Rubaka C C 2002 Pastoral Neolithic settlement and subsistence patterns in the Mang'ola graben, Tanzania. MA dissertation, University of Dar es Salaam.

Solana DC, Zugasti IG and Conte IC 2011 The use of mollusc shells as tools by coastal human groups: the contribution of ethnographical studies to research on mesolithic and early Neolithic technologies in northern Spain. J. Anthropol. Res. 67(1): 77-102.

Walz J 2017 Toward an ethnoarchaeomalacology of Achatina in East Africa. Ethnobiol. Lett. 8(1): 90-96.

Wang K, Goldstein S, Bleasdale M, Clist B, Bostoen K, Bakwa-Lufu P, Buck LT, Crowther A, D'eme A, McIntosh RJ, Mercader J, Ogola C, Power RC, Sawchuk E, Robertshaw P, Wilmsen EN, Petraglia M, Ndiema E, Manthi FK, Krause J, Roberts P, Boivin N and Schiffels S 2020 Ancient genomes reveal complex patterns of population movement, interaction, and replacement in sub- Saharan Africa. Sci. Adv. 6(24): eaaz0183.

Wright DK 2011 Frontier animal husbandry in the Northeast and East African Neolithic: a multiproxy paleoenvironmental and paleodemographic study. J. Anthropol. Res. 67: 213-244. 